\title{
PENGEMBANGAN BAHAN AJAR IPA BERBASIS SETS PADA SISWA MTsN 1 KENDARI
}

\author{
Abdul Kadir \\ Fakultas Tarbiyah dan Ilmu Keguruan Institut Agama Islam Negeri Kendari \\ abdir_edu@yahoo.co.id
}

\begin{abstract}
This study aims to produce the valid SETS-based science teaching materials for the practical and effective use in improving student learning outcomes on environmental pollution materials. This research is Research and Development with pretest-posstest one group design implemented at VII class' students of MTsN 1 Kendari in the second semester of academic year 2015/2016. The instruments of the study are valid and reliable observations, questionnaires and cognitive tests to obtain the required data. Meanwhile, the data analysis technique is using descriptive and inferential analysis after meeting the normality and homogeneity requirements test. The results indicate; 1) the results of the validity of the SETS-based science test materials by the material and media experts which are valid and highly feasible materials to use, 2) the product practicality test results in small and large group samples which include all aspects considered to be generally implemented as a whole, and 3) the product effectiveness test results obtained through the average test of student learning outcomes before and after treatment which is significantly different, meaning that students' learning outcomes after treatment is increase. While the response of students and teachers on teaching materials used both in small and large group samples are both very good and suitable to use as a learning material on environmental contamination material in MTsN 1 Kendari.
\end{abstract}

\section{Keywords: SETS Based Teaching Materials and Learning Outcomes}

\begin{abstract}
Abstrak
Penelitian ini bertujuan untuk mengulas dan menghasilkan bahan ajar IPA berbasis SETS yang valid, praktis dan efektif digunakan dalam meningkatkan hasil belajar siswa pada materi pencemaran lingkungan. Penelitian ini adalah Research and Development dengan rancangan pretest-posstest one group design yang dilaksanakan di MTsN 1 Kendari pada siswa kelas VII semester genap tahun pelajaran 2015/2016. Instrumen dan teknik pengumpulan data digunakan adalah observasi, kuesioner dan tes kognitif yang valid dan reliabel. Sedangkan teknik analisis datanya menggunakan analisis deskriptif dan inferensial setelah memenuhi uji persyaratan normalitas dan homogenitas. Hasil penelitian diperoleh bahwa hasil uji kevalidan bahan ajar IPA berbasis SETS oleh pakar materi dan media adalah bahan ajar valid dan sangat layak untuk digunakan. Hasil uji kepraktisan produk pada sampel kelompok kecil dan besar adalah seluruh aspek yang dinilai pada umumnya
\end{abstract}


telah terlaksana secara keseluruhan. Hasil uji keefektifan produk diperoleh melalui pengujian rerata hasil belajar siswa sebelum dan sesudah perlakuan adalah terdapat perbedaaan yang signifikan, artinya hasil belajar siswa sebelum diberikan perlakuan meningkat menjadi lebih baik setelah perlakuan. Sedangkan respon siswa dan guru terhadap bahan ajar yang digunakan baik pada sampel kelompok kecil dan besar adalah keduanya termasuk kategori sangat baik atau sangat layak untuk dipergunakan sebagai bahan pembelajaran pada materi pencemaran lingkungan di MTsN 1 Kendari.

\section{Kata Kunci: Bahan Ajar Berbasis SETS dan Hasil Belajar}

\section{A. PENDAhuluan}

Proses pembelajaran di dalam kelas tidak lepas dari kurikulum pendidikan yang diberlakukan. Kurikulum merupakan perangkat mata pelajaran dan program pendidikan yang diberikan oleh suatu lembaga penyelenggara pendidikan yang berisi rancangan pembelajaran yang diberikan kepada peserta didik dalam suatu periode jenjang pendidikan.

Dalam Peraturan Menteri Pendidikan dan Kebudayaan Republik Indonesia Nomor 68 Tahun 2013 tentang Kerangka Dasar dan Struktur Kurikulum SMP/MTs, dikemukakan bahwa IPA merupakan salah satu mata pelajaran yang berbasis konsep-konsep terpadu dari berbagai displin ilmu. IPA dikembangkan dalam bentuk integrated sciences yang berasal dari disiplin biologi, fisika dan kimia. Namun Trianto menyebutkan berbagai kelemahan yang ada dalam pembelajaran IPA terpadu, diantaranya pada aspek guru, peserta didik, sarana dan sumber pembelajaran, kurikulum, penilaian, dan suasana pembelajaran. ${ }^{1}$

Pembelajaran IPA di sekolah/madrasah diajarkan secara terpadu namun masih bersifat teoritis, belum banyak mengaitkan dengan permasalahan yang dihadapi peserta didik dalam kehidupan riil sehari-hari, kegiatan pembelajaran belum optimal dan cenderung berpusat pada guru, serta belum melatih peserta didik untuk berpikir ilmiah. Belum diterapkannya pembelajaran IPA terpadu disebabkan oleh beberapa faktor diantaranya adalah sebagian guru masih mengalami kesulitan untuk merancang pembelajaran terpadu berdasarkan standar isi untuk kurikulum IPA dan keterbatasan bahan ajar pembelajaran IPA terpadu. Menurut Kumala, bahwa ada banyak kendala yang mengakibatkan guru belum menerapkan pembelajaran IPA secara terpadu, yaitu 1) guru berasal dari latar belakang pendidikan fisika, biologi dan kimia. 2) buku yang disediakan oleh pemerintah belum menyajikan IPA secara terpadu dan 3) keterbatasan

\footnotetext{
${ }^{1}$ Trianto, Model Pembelajaran Terpadu. (Jakarta: Bumi Aksara, 2011), h. 4
} 
kemampuan guru untuk merancang bahan ajar IPA terpadu. ${ }^{2}$ Hal ini berdampak pada pelaksanaan pembelajaran yang dilakukan guru yang tidak maksimal dan menyebabkan pada pencapaian hasil belajar peserta didik yang belum maksimal.

Berdasarkan hasil observasi awal terkait dengan penggunaan bahan ajar dalam mata pelajaran IPA, bahwa sumber belajar yang digunakan oleh guru di madrasah masih berupa buku-buku yang diterbitkan oleh pemerintah, lembar kerja siswa, dan beberapa buku yang relevan dari penerbit tertentu. Bahan ajar yang digunakan oleh guru-guru tersebut belum menyajikan IPA secara terpadu. Bahan ajar IPA terpadu yang digunakan oleh guru merupakan kumpulan bahan ajar dari kajian Kimia, Biologi, dan Fisika yang dijadikan dalam satu buku. Jika dilihat dari segi konten, antara Kimia, Fisika dan Biologi masih belum ada keterkaitan satu dengan yang lainnya.

Dalam beberapa hasil penelitian yang telah dilakukan, pembelajaran IPA terpadu menunjukkan pengaruh yang positif terhadap hasil belajar siswa. Hasil penelitian yang dilakukan oleh Listyawati mengungkapkan bahwa pengembangan perangkat IPA terpadu di SMP dapat meningkatkan hasil belajar siswa. ${ }^{3}$ Hal serupa diperoleh oleh Yuliati menemukan bahwa kemampuan berpikir siswa yang menggunakan bahan ajar IPA terpadu lebih baik dibanding kemampuan berpikir siswa yang menggunakan bahan ajar IPA yang parsial. ${ }^{4}$ Lebih jauh dikemukakan, bahwa bahan ajar IPA yang disajikan dengan menyampaikan permasalahan yang riil dan kontekstual dapat mempermudah pelaksanaan pembelajaran IPA. ${ }^{5}$

Berdasarkan beberapa hasil penelitian tersebut jelas bahwa pembelajaran IPA di SMP sebaiknya dilakukan secara terpadu, sehingga pengembangan bahan ajar IPA terpadu adalah hal yang penting dilakukan agar pembelajaran IPA terpadu dapat terlaksana. Penyajian konsep dalam bahan ajar IPA terpadu dimulai dari fenomena yang ada di alam dan dekat dengan siswa agar dapat lebih mudah memahaminya.

Dalam menunjang tercapainya proses pembelajaran IPA yang optimal, bahan ajar merupakan komponen yang sangat penting dan perlu

\footnotetext{
${ }^{2}$ Kumala, D. "Pengembangan Perangkat Pembelajaran IPA Terpadu dengan Setting Inkuiri Terbimbing untuk Meningkatkan Pemahaman Konsep dan Kinerja Ilmiah Siswa". EJournal Program Pascasarjana Universitas Pendidikan Ganesha, 2013.

${ }^{3}$ Listyawati, "Pengembangan Perangkat Pembelajaran IPA Terpadu di SMP". Journal of Innovative Science, Vol. 1, (2012): 61- 69.

${ }^{4}$ Yuliati, L. "Efektivitas Bahan Ajar IPA Terpadu terhadap Kemampuan Berpikir Tingkat Tinggi Siswa SMP”, Jurnal Pendidikan Fisika Indonesia, Vol. 9, (2013): 53-57.

${ }^{5}$ M. Lang \& Olson, Integrated Science Teaching as a Challenge for Teachers to Develop New Conceptual Structures. Journal Research in Science Education, Vol. 30, No. 2, (2000): 213-224.
} 
mendapat perhatian yang khusus. Masih banyak bahan ajar yang keluasan dan kedalaman materinya belum sesuai dengan tingkat perkembangan siswa sehingga tidak mudah untuk dipahami siswa. Pengembangan bahan ajar IPA terpadu di SMP juga harus mempertimbangkan tingkat keluasan, kedalaman materi, kebenaran materi, struktur materi, sampai pada aspek grafika dan aspek penyajian materi. $^{6}$

Peraturan Menteri Pendidikan Nasional, menyatakan bahwa di tingkat SMP/MTs diharapkan ada penekanan pembelajaran IPA yang berbasis sains, lingkungan, teknologi dan masyarakat atau dalam istilah SETS (Science, Environmental, Technology and Society) yang secara terpadu. ${ }^{7}$ Pernyataan ini didukung oleh hasil penelitian Frank dan Barzilai, bahwa 95\% siswa berpendapat jika konsep sains, lingkungan, teknologi, dan masyarakat dimasukkan ke dalam proses pembelajaran, maka dapat memberikan kesempatan peserta didik untuk memperoleh pengetahuan dan mempertinggi pemahaman mereka antar cabang ilmu pengetahuan sehingga dapat memiliki pemikiran tentang hasil teknologi dari transformasi sains dalam bentuk teknologi, tanpa harus merusak atau merugikan lingkungan dan masyarakat. ${ }^{8}$

Berdasarkan latar belakang, fenomena lapangan, kajian teori dan hasil penelitian di atas, maka salah satu jenis sumber belajar yang dapat dikembangkan yakni berupa bahan ajar IPA berbasis SETS. Bagi peserta didik, bahan ajar IPA tersebut diasumsikan dapat membantu peserta didik berpikir secara utuh dan sistematis tentang IPA sehingga dapat dipelajari secara mandiri. Sedangkan bagi guru, akan mempermudah dalam merancang dan melakukan pembelajaran IPA karena bahan ajar tersebut memuat tujuan pembelajaran, bahan dan kegiatan untuk mencapai tujuan serta evaluasi terhadap pencapaian tujuan pembelajaran.

Tulisan ini akan mengulas tentang bagaimana pengembangan bahan ajar IPA berbasis SETS dengan konsep "Pencemaran Lingkungan" secara valid, praktis dan efektif dapat meningkatkan hasil belajar peserta didik di MTsN 1 Kendari dengan menggunakan metode penelitian pengembangan (research and development) yang mengadaptasi model penelitian Borg dan Gall dengan pengembangan perangkatnya mengadaptasi model

${ }^{6}$ Syaeful, Anwar, Pengolahan Bahan Ajar. (Bandung: UPI Press, 2014), h. 2

${ }^{7}$ Permendiknas No 22 Tahun 2006 tentang Standar Isi Satuan Pendidikan Dasar dan Menengah, http://www.permen_22_2006, diakses 30 Maret 2016.

${ }^{8}$ Frank dan Barzilai. "Project-Based Technology: Instructional Strategy for Developing Technological Literacy". Journal of Technology Education, Vol. 18, No. 1, (2006): 39-53. 
pengembangan ADDIE yang meliputi 4 tahapan yaitu (1) tahap analisis, (2) tahap desain, (3) tahap pengembangan, (4) tahap implementasi dan evaluasi. ${ }^{9}$

Subjek penelitian ini melibatkan tiga orang ahli pendidikan yang terdiri dari ahli materi (content) dan ahli media pembelajaran yang berperan untuk menguji validitas produk yang dikembangkan, siswa dan guru IPA berperan dalam memperoleh data tentang kepraktisan dan efektivitas produk. Siswa yang dimaksud adalah siswa kelas VII yang merupakan sampel pada tahap implementasi produk (eksperimen) tediri dari 12 orang untuk ujicoba sampel kelompok kecil dan 24 orang siswa untuk uji coba sampel kelompok besar. Pelaksanaan eksperimen menggunakan desain pretest-posttest one group design, yang pembelajarannya dilaksanakan oleh guru IPA MTsN 1 Kendari.

Instrumen penelitian dan teknik pengumpulan data penelitian ini menggunakan teknik1) observasi adalah lembar/format pengamatan dan penilaian untuk uji kevalidan, kepraktisan oleh ahli/pakar dan reviewer terhadap desain produk yang dikembangkan, 2) tes, adalah pertanyaan tertulis bentuk pilihan ganda diberikan untuk mengetahui hasil belajar yang dicapai peserta didik sebelum dan sesudah pembelajaran dengan menggunakan bahan ajar IPA berbasis SETS, dan 3) kuesioner adalah bentuk pertanyaan/pernyataan tertutup yang diberikan kepada siswa dan guru tentang respon terhadap penggunaan bahan ajar IPA berbasis SETS.

Teknik analisis data yang digunakan dalam penelitian ini dapat, diuraikan sebagai berikut:

1) Analisis data kevalidan dan kepraktisan produk oleh pakar. Datanya direkam menggunakan instrumen kevalidan dan kepraktisan produk yang dianalisis secara deskriptif kualitatif. Kriteria pengujian kevalidan dan kepraktisan produk diukur melalui tabel kategori berikut. ${ }^{10}$

\section{Tabel 1. Kriteria Kevalidan Produk}

\begin{tabular}{clll}
\hline Validitas (V) & \multicolumn{1}{c}{ Kategori } & \multicolumn{1}{c}{$\%$} & Kategori \\
$3,5 \leq \mathrm{V} \leq 4$ & Sangat Valid & $81.28<\mathrm{P} \leq 100$ & $\begin{array}{l}\text { Sangat } \\
\text { Layak }\end{array}$ \\
& (SV) & & Layak \\
$2,5 \leq \mathrm{V} \leq 3,4$ & Valid (V) & $62.52<\mathrm{P} \leq$ & \\
& & 81.27 & \\
$1,5 \leq \mathrm{V} \leq 2,4$ & Cukup Valid & $43.76<\mathrm{P} \leq$ & Cukup \\
& (CV) & 62.51 & Layak \\
$\mathrm{V} \leq 1,4$ & Tidak Valid (TV) & $25<\mathrm{P} \leq 43,75$ & Tidak Layak \\
\hline
\end{tabular}

${ }^{9}$ I Wayan, Sukardjita, "Pengembangan Model Pembelajaran IPA MOTORIC Berwawasan Lingkungan Bagi Siswa SMP di Kota Kupang”, Diisertasi Doktor, (Makassar: PPs UNM, 2015), h. 137

${ }^{10}$ Ibid, h. 137 


\section{Tabel 2. Kriteria Kepraktisan (Keterlaksanaan) Produk}

\begin{tabular}{cc}
\hline Keterlaksanaan $(\mathrm{M})$ & \multicolumn{1}{c}{ Kategori } \\
$1,5 \leq \mathrm{M} \leq 2,0$ & Terlaksana Seluruhnya \\
$0,5 \leq \mathrm{M}<1,4$ & Terlaksana Sebahagian \\
$0,0 \leq \mathrm{M}<0,4$ & Tidak Terlaksana \\
\hline
\end{tabular}

Selanjutnya untuk mengetahui tingkat reliabilitas data dari dua orang validator untuk aspek yang sama, maka perlu dilakukan analisis uji kesepahaman dengan menggunakan persamaan Borich, sebagai berikut.

$$
R=\frac{\text { Agreeement }(A)}{\text { Disagreements }(D)+\text { greeement }(A)} \times 100 \%{ }^{11}
$$

Keterangan:

A: besarnya frekuensi kecocokan antara data dua pengamat

D: besarnya frekuensi ketidak cocokan antara data dua pengamat

$\mathrm{R}$ : koefisien (derajat) reliabilitas instrumen

2) Analisis keefektifan produk, diukur melalui; (a) Analisis data respon siswa terhadap produk bahan ajar yang digunakan. Produk pembelajaran yang diujicobakan dikatakan efektif jika sekurang-kurangnya $75 \%$ dari siswa memberikan respon positif terhadap produk yang diujicobakan, (b) Analisis data hasil belajar siswa. Data hasil belajar siswa terdiri dari nilai pretes dan postes yang direkam melalui pemberian tes hasil belajar setelah proses pembelajaran menggunakan produk yang dikembangkan. Data hasil belajar tersebut dianalisis secara statistika deskriptif dan inferensial. Analisis statistika deskriptif berupa; menghitung nilai ratarata, maksimum, minimum, rentang, standar deviasi, variansi, distribusi frekuensi, persentase, dan kategorisasi. Sedangkan analisis inferensial dilakukan setelah menguji kenormalan data dan homogenitas varian, selanjutnya dilakukuan pengujian hipotesis penelitian dengan menggunakan uji-t ( $t$-test).

\section{B. PEMBELAJARAN IPA BERBASIS SCIENCE ENVIRONMENT TECHNOLOGY AND SOCIETY (SETS)}

Ilmu Pengetahuan Alam (IPA) merupakan suatu kumpulan pengetahuan yang tersusun secara sistematis, dan dalam penggunaannya secara umum terbatas pada gejala-gejala alam. Perkembangan IPA

${ }^{11}$ Borich, Gary D. Effective Teaching Methods Reasearch Based Practice. (New Jersey: Pearson Education Inc, 2007), h.87 
selanjutnya tidak hanya ditandai oleh adanya kumpulan fakta saja, tetapi juga munculnya metode ilmiah (scientific methods) yang terwujud melalui suatu rangkaian kerja ilmiah (working scientifically), nilai dan sikap ilmiah (scientific attitudes).

IPA merupakan ilmu yang pokok bahasanya adalah alam dan segala isinya. Secara umum IPA di SMP/MTs meliputi bidang kajian Energi dan perubahannya, Bumi dan alam semesta, makhluk hidup dan proses kehidupan, Materi dan sifatnya, di mana semua kajian tersebut sangat berperan dalam membantu peserta didik untuk memahami fenomena alam. IPA merupakan pengetahuan ilmiah, yaitu pengetahuan yang telah mengalami uji kebenaran melalui metode ilmiah, dengan ciri objektif, metodik, sistematis, universal, dan tentatif atau bersifat sementara. ${ }^{12}$ Sedangkan menurut Carin dan Sund, IPA didefinisikan sebagai pengetahuan sistematis dan tersusun secara teratur berlaku umum (universal), dan berupa kumpulan data hasil observasi dan eksperiment ${ }^{13}$.

Merujuk pada pengertian IPA di atas, maka hakikat IPA meliputi 4 (empat) unsur, yaitu (1) produk; berupa fakta, prinsip, teori, dan hukum; (2) proses; yaitu prosedur pemecahan masalah melalui metode ilmiah, evaluasi, pengukuran, dan penarikan kesimpulan; (3) aplikasi; merupakan penerapan metode atau kerja ilmiah dan konsep IPA dalam kehidupan sehari-hari; (4) sikap; yang terwujud melalui rasa ingin tahu tentang obyek, fenomena alam, makhluk hidup, serta hubungan sebab akibat yang menimbulkan masalah baru namun dapat dipecahkan melalui prosedur yang benar.

Adapun konsep SETS merupakan suatu konsep pendekatan pembelajaran dalam sains yang memandang bahwa belajar sains tidak sebagai satu disiplin ilmu yang terpisah dari social (kehidupan), melainkan siswa belajar sains sebagai suatu ilmu di satu sisi dan sains yang memiliki keterkaitan dengan technology dan society di sisi lain dalam satu wadah yang tak terpisahkan. ${ }^{14}$

Model pembelajaran SETS yang meliputi sains, lingkungan, teknologi dan masyarakat, yaitu memadukan pemikiran STS (Science, Technology and Society) dan EE (Environment Education) dengan memberi filosofi baru di

\footnotetext{
${ }^{12}$ Depdiknas, Model Pengembangan Silabus Mara Pelajaran dan Rencana Pelaksanaan Pembelajaran IPA Terpadu SMP/MTs, (Jakarta: Pusat Kurikulum. Balitbang Depdiknas, 2006a).

${ }^{13}$ Carin dan Sund, Teaching Science Trough Discovery. (Columbus: Merril Publishing Company, 1993).

${ }^{14}$ Woolnough, B. Practical Work in Science. (Cambirge: University Press, 1991), h. 24
} 
dalamnya. ${ }^{15}$ Tujuan strategi pembelajaran SETS adalah membantu siswa mengetahui sains dan perkembangannya serta bagaimana perkembangan sains dapat mempengaruhi lingkungan teknologi dan masyarakat.

Model Pembelajaran SETS secara garis besar ada 5 tahap yaitu 1) invitasi, bertujuan untuk merumuskan masalah dan mengetahui hubungan dengan pengetahuan sebelumnya, 2) eksplorasi, berisi tentang eksperiment atau aktivitas fisik, melakukan observasi menggunakan kelima panca indra, interaksi sosial sampai pengambilan keputusan, 3) pengenalan konsep, berisi diskusi yang yang dipandu oleh guru dengan memberikan suasana sehingga siswa aktif bertanya dengan tujuan meluruskan pengetahuan yang diperoleh secara ilmiah, 4) aplikasi, berupa aktivitas tambahan untuk mengaplikasikan konsep yang diperoleh dalam konteks yang berbeda, dan 5) evaluasi, penilaian terhadap hasil yang telah dilakukan selama pendekatan pembelajaran diterapkan.

\section{BAHAN AJAR IPA BERBASIS SCIENCE ENVIRONMENT TECHNOLOGY AND SOCIETY (SETS)}

Bahan ajar merupakan bahan-bahan atau materi kegiatan pembelajaran yang disusun secara sistematis yang digunakan siswa dan guru dalam proses pembelajaran. Bahan ajar sangat menentukan keberhasilan pendidikan para siswa dalam menuntut pelajaran di sekolah. Bahan ajar yang dirancang sesuai dengan kurikulum yang berlaku akan mengarahkan proses pembelajaran pada arah yang benar sesuai tuntutan kurikulum. Menurut Soegiranto, bahwa bahan ajar adalah bahan atau materi yang disusun oleh guru secara sistematis yang digunakan peserta didik (siswa) dalam pembelajaran yang dikemas dalam bentuk cetakan, non cetak dan bersifat visual auditif yang disusun dalam buku ajar pendidik dapat berbentuk modul. ${ }^{16}$

Bahan ajar yang baik adalah bahan ajar yang menjadi sumber ilmu pengetahuan, sehingga dapat menjadi media yang baik dan akan membantu mengoptimalkan proses pembelajaran. Jenis bahan ajar yang demikian diharapkan dapat membantu proses pembelajaran yang efektif dan efisien, sehingga dapat meningkatkan mutu pendidikan, khususnya pendidikan IPA. Jenis bahan ajar yang diharapkan adalah bahan ajar yang dapat menunjang terselenggaranya pembelajaran dengan pendekatan konstruktif sehingga buku

15 Binadja, Achmad, Pendidikan IPA dan Pemikiran dalam SETS (Science, Enviroment, Technology, Society. (Semarang: PPS Unnes Press, 2002)

${ }^{16}$ Soegiranto, Acuan Penulisan Bahan Ajar Dalam Bentuk Modul. (Provinsi Nusa Tenggara Timur: Pokja Kurikulum dan Supervisi Pusat Pengembangan Madrasah Kementrian Agama, 2010), h. 17 
tersebut dapat menjadi sumber inspirasi, dan sumber informasi baik bagi siswa maupun guru.

Suatu proses pembelajaran akan lebih bermakna jika siswa sendiri yang aktif dalam mengkonstruksi pengetahuannya. Salah satunya adalah bahan ajar yang berbasis Science Environment Technology And Society (SETS). Bahan ajar IPA berbasis SETS merupakan bahan ajar yang di dalamnya membahas beberapa bidang kajian yang dipadukan karena masih memiliki keterkaitan dan dipadukan dengan satu tema/topik tertentu dengan mengaitkan antara sains, lingkungan, teknologi dan masyarakat sebagai model pembelajarannya.

Pengembangan bahan ajar IPA berbasis SETS ini diawali dengan mempelajari kompetensi inti dan dilanjutkan dengan mempelajari kompetensi dasar. Berdasarkan kompetensi inti dan kompetensi dasar tersebut, kemudian dijabarkan menjadi beberapa indikator belajar, setelah itu menentukan tema pembelajaran. Dari tema tersebut, kemudian disusun isi materi pembelajaran. Materi pembelajaran tersebut disusun dengan mengaitkan antara sains, lingkungan, teknologi dan masyarakat sebagai model pembelajarannya dengan mengacu pada sintaks pembelajaran SETS, yakni invitasi, eksplorasi, pengenalan konsep, aplikasi dan evaluasi.

Dengan demikian, penerapan model pembelajaran yang benar adalah yang sesuai dengan prinsip-prinsip dan kriteria bahan ajar itu sendiri dalam hal ini menggunakan model pembelajaran SETS sebaiknya disertai dengan bahan ajar berbasis SETS. Apabila model pembelajaran yang digunakan tidak memperhatikan bahan ajar yang dipakai maka dimungkinkan tujuan pembelajaran belum dapat tercapai secara maksimal.

\section{PENGEMBANGAN BAHAN AJAR IPA BERBASIS SETS PADA SISWA MTsN 1 KENDARI}

Hasil penelitian pengembangan Bahan Ajar IPA Berbasis SETS dalam meningkatkan hasil belajar yang dilakukan di MTsN 1 Kendari diuraikan dalam beberapa tahapan, meliputi (1) studi pendahuluan, (2) pengembangan bahan ajar mencakup penyusunan desain, dan (3) implementasi (uji coba) bahan ajar meliputi uji coba sampel kelompok kecil (terbatas) dan uji coba sampel kelompok besar (lebih luas).

\section{Hasil Studi Pendahuluan}

Observasi awal yang dilakukan di MTsN 1 Kendari menunjukkan bahwa belum ada bahan ajar berupa modul yang digunakan dalam pembelajaran IPA. Hasil angket yang diberikan kepada siswa diperoleh data $81,67 \%$ siswa merasa tidak puas terhadap hasil belajar yang dicapai. Sebanyak $75,83 \%$ siswa menyatakan bahan ajar yang tersedia tidak membuat mereka belajar mandiri dan sebanyak 95,83\% membutuhkan bahan ajar baru 
yang dapat meningkatkan hasil belajar siswa. Ketika penulis menyampaikan akan membuat bahan ajar modul materi Pencemaran Lingkungan, maka sebanyak $100 \%$ siswa menyatakan setuju.

Hasil angket yang diberikan kepada guru menyatakan bahwa hasil belajar IPA siswa pada materi pencemaran lingkungan belum memuaskan. Terdapat $75 \%$ guru menyatakan bahwa siswa tidak belajar secara mandiri dengan bahan ajar yang digunakan saat ini, dan sebanyak $100 \%$ guru membutuhkan media lain dapat berupa bahan ajar untuk meningkatkan hasil belajar siswa.

Deskripsi di atas menunjukkan adanya potensi dan kondisi yang mendukung untuk dikembangkannya bahan ajar IPA berbasis SETS pada materi Pencemaran Lingkungan. Produk awal yang dikembangkan berjudul "Bahan Ajar IPA Berbasis SETS pada Konsep Pencemaran Lingkungan di MTsN 1 Kota Kendari”.

\section{Hasil Pengembangan Produk}

Produk yang dikembangkan yaitu bahan ajar IPA berbasis SETS pada materi pencemaran lingkungan dikonsultasikan dan dinilai terlebih dahulu kepada validator materi untuk mengetahui kelayakan dari bahan ajar tersebut apabila digunakan sebagai bahan ajar. Penilaian yang digunakan mangacu pada instrumen penilaian buku teks pelajaran. Badan Standar Nasional Pendidikan (BSNP) 2006. Hasil validasi oleh pakar materi (isi), bahasa, media dan penyajian sebagaimana disajikan pada gambar berikut:

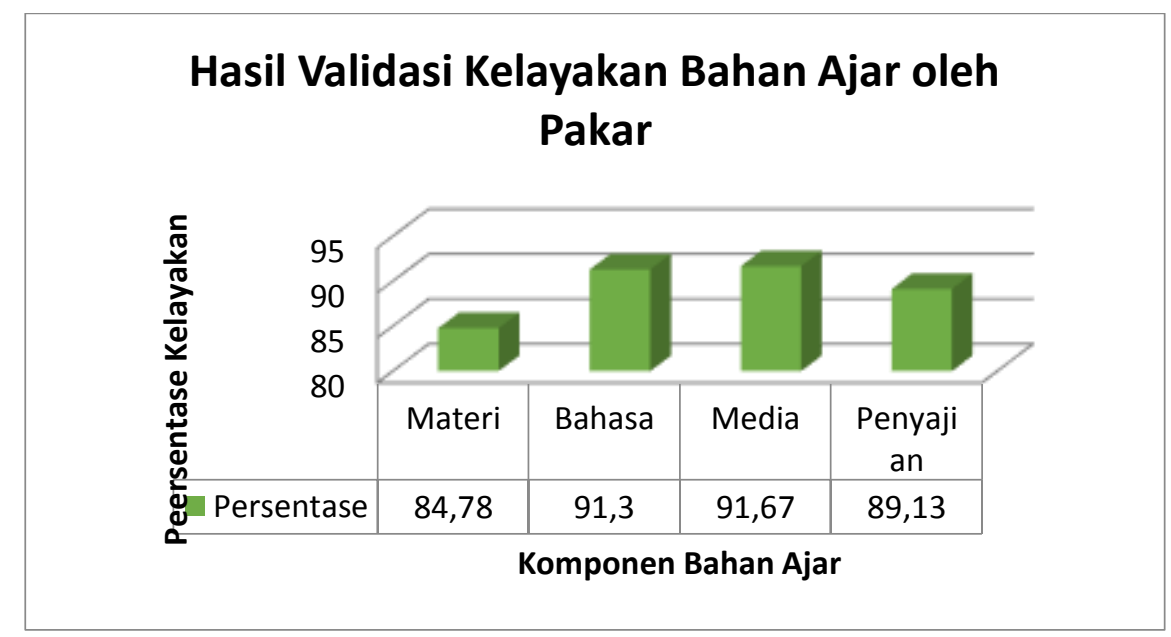

Gambar 1; Grafik Hasil Validasi Bahan Ajar oleh Pakar

Berdasarkan hasil penilaian oleh validator materi diperoleh 84,78\%, 
validator bahasa $91,3 \%$, validator media $91,67 \%$, dan validator penyajian $89,13 \%$. Skor persentase penilaian tersebut termasuk dalam rantang $81,25 \%$ $<\mathrm{p} \leq 100 \%$, artinya bahan ajar yang dikembangkan adalah valid dengan kategori sangat layak untuk dijadikan sebagai bahan ajar pada materi pembelajaran pencemaran lingkungan. Validator juga menambahkan saran soal-soal yang terdapat dalam bahan ajar dilengkapi dengan keterangan gambar atau grafik dan huruf yang digunakan untuk penulisan sumber gambar diperkecil lagi.

\section{Hasil Tahap Implementasi dan Evaluasi}

Implementasi dan evaluasi merupakan tahap akhir dari tahapan penelitian dan pengembangan. Produk akhir yang sudah valid setelah melalui tahapan validasi pada tahap pengembangan selanjutnya diimplementasikan melalui serangkaian iju coba, baik uji coba pada kelompok kecil (terbatas) maupun kelompok besar (lebih luas). Implementasi pada kelompok kecil dan kelompok besar ini bertujuan untuk menguji kepraktisan dan keefektifan produk bahan ajar IPA berbasis SETS.

\section{a. Hasil Uji Kepraktisan Produk}

Data kepraktikan bahan ajar yang direkam melalui hasil observasi keterlaksanaan perangkat pembelajaran IPA berbasis SETS, meliputi (1) aspek keterlaksanaan sintaks pembelajaran, (2) aspek interaksi sosial, (3) aspek prinsip reaksi (4) aspek sistem pendukung dan (5) aspek kemudahan. Ringkasan hasil observasi keterlaksanaan bahan ajar pada uji coba kelompok kecil dan besar disajikan pada tabel berikut:

Tabel 3. Hasil Observasi Keterlaksanaan Bahan Ajar

\begin{tabular}{|c|c|c|c|}
\hline \multirow{2}{*}{ No } & \multirow{2}{*}{ Aspek yang Dinilai } & \multicolumn{2}{|c|}{ Hasil Observasi Kelompok } \\
\hline & & Kecil & Besar \\
\hline 1. & Keterlaksanaan Sintaks & 1,67 & 1,78 \\
\hline 2. & Interaksi sosial & 1,50 & 2,00 \\
\hline 3. & Prinsip reaksi & 1,73 & 1,80 \\
\hline 4. & Sistem pendukung & 1,78 & 1,89 \\
\hline 5. & Kemudahan & 1,50 & 1,50 \\
\hline & Jumlah & $\mathbf{8 , 1 8}$ & 8,97 \\
\hline \multicolumn{2}{|c|}{ Rerata Total Seluruh Aspek } & 1,64 & 1.79 \\
\hline \multicolumn{2}{|c|}{ Persentase $(\%)$} & 81,78 & 89,67 \\
\hline & Kategori & \multicolumn{2}{|c|}{ Terlaksana Seluruhnya } \\
\hline
\end{tabular}

Sumber: Hasil Pengolahan Data, 2016 
Berdasarkan hasil observasi keterlaksanaan bahan ajar untuk seluruh aspek yang diamati pada tabel di atas, diperoleh skor rata-rata 1,64 atau $81,78 \%$ pada kelompok kecil dan 1,79 atau $89,67 \%$ pada kelompok besar. Skor rata-rata dan persentase penilaian tersebut berada pada interval 1,5 $\leq$ Mean $\leq 2,0$, artinya kelima aspek yang diukur pada umumnya telah terlaksana secara keseluruhan, sehingga dapat dinyatakan bahwa bahan ajar IPA berbasis SETS sebagai produk dalam penelitian pengembangan ini dikatakan sebagai produk yang memiliki nilai kepraktisan untuk dapat diterapkan dalam proses pembelajaran IPA pada konsep pencemaran lingkungan.

\section{b. Hasil Uji Keefektifan Produk}

\section{1) Hasil Analisis Tes Kognitif}

Data nilai hasil belajar peserta didik diperoleh dari hasil tes kognitif tentang materi pencemaran lingkungan yang dilakukan pada kelompok kecil dan kelompok besar sebagaimana disajikan pada gambar berikut:

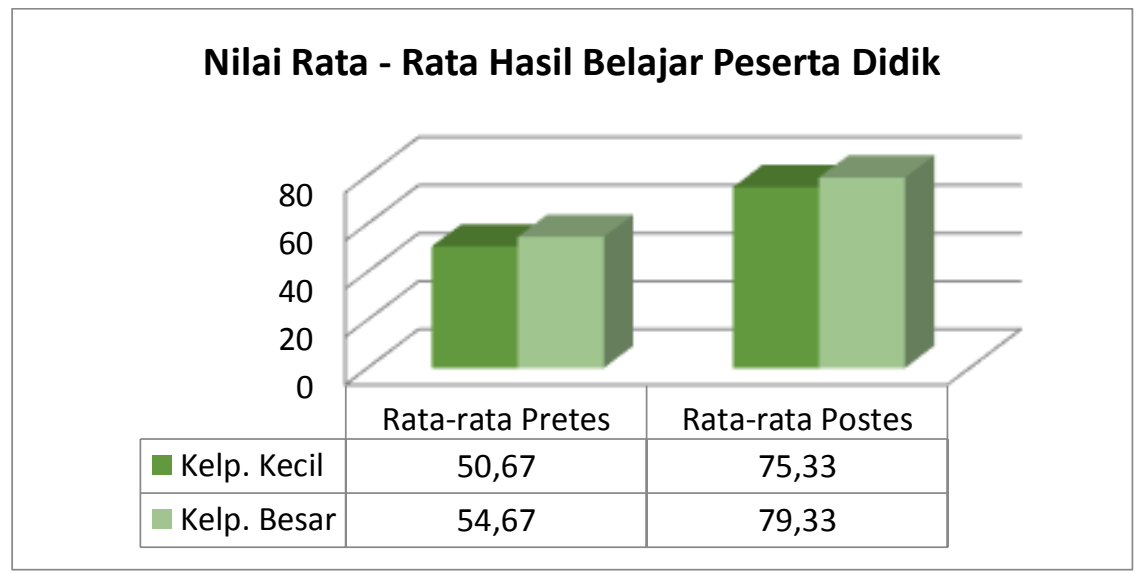

\section{Gambar 2; Grafik Rata-Rata Hasil Belajar Peserta Didik}

Berdasarkan hasil tes kognitif peserta didik sebelum dan sesudah pembelajaran dengan menggunakan bahan ajar IPA berbasis SETS sebagaimana pada grafik di atas, diperoleh nilai rata-rata pretes kelompok kecil sebesar 50,67 dan 54,67 pada kelompok besar. Hal ini menandakan bahwa peserta didik pada kedua kelompok tersebut memiliki kemampuan awal yang sama sebelum melakukan pembelajaran. Sedangkan nilai hasil belajar peserta didik setelah melakukan pembelajaran dengan menggunakan bahan ajar IPA berbasis 
SETS diperoleh nilai rata-rata sebesar 75,33 pada kelompok kecil dan 79,33 kelompok besar. Perolehan nilai tersebut menandakan bahwa hasil belajar peserta didik pada kedua kelompok tersebut mengalami peningkatan. Hal ini dapat dimaknai bahwa bahan ajar IPA yang dikembangkan dapat memberikan kontribusi terhadap peningkatan hasil belajar peserta didik.

\section{a. Pengujian Persyaratan:}
1) Uji Normalitas

Tabel 4. Ringkasan Hasil Pengujian Normalitas Data Penelitian

\begin{tabular}{ccccc}
\hline Kelompok & $\begin{array}{c}\text { Kelompok } \\
\text { Data }\end{array}$ & Sig (p) & A & Kesimpulan \\
\hline Kecil & Pretes & 0,973 & & Normal \\
\cline { 2 - 3 } (Terbatas) & Postes & 0,954 & 0,05 & Normal \\
\hline Besar & Pretes & 0,679 & & Normal \\
\cline { 2 - 3 } (Lebih Luas) & Postes & 0,455 & & Normal \\
\hline
\end{tabular}

Sumber: Output Hasil Pengujian SPSS 21

\section{Kriteria:}

- Jika probabilitas $(\boldsymbol{\rho})>0,05$, maka Ho diterima dan disimpulkan bahwa nilai residual (error) menyebar normal. Jika Probabilitas $(\boldsymbol{\rho})<0,05$ maka Ho ditolak dan disimpulkan bahwa nilai residual (error) menyebar tidak normal.

\section{2) Uji Homogenitas}

Tabel 5. Ringkasan Hasil Pengujian Homogenitas Varian

\begin{tabular}{|c|c|c|c|c|c|c|c|c|}
\hline \multicolumn{9}{|c|}{ Test of Homogeneity of Variances } \\
\hline \multicolumn{3}{|c|}{ Kelompok Variansi } & $\begin{array}{l}\text { Levene } \\
\text { Statisti }\end{array}$ & df1 & df2 & Sig. (p) & $\alpha$ & Kesimpulan \\
\hline \multirow{2}{*}{$\begin{array}{l}\text { Nilai Hasil } \\
\text { Belajar }\end{array}$} & 1 & $\begin{array}{l}\text { Pretes \& Postes } \\
\text { (Kelompok Kecil) }\end{array}$ & 0,184 & 1 & 22 & 0,672 & \multirow{2}{*}{0,05} & Homogen \\
\hline & 2 & $\begin{array}{l}\text { Pretes \& Postes } \\
\text { (Kelompok Besar) }\end{array}$ & 0,353 & 1 & 46 & 0,555 & & Homogen \\
\hline
\end{tabular}

Sumber: Output Hasil Pengujian SPSS 21

Kriteria:

- Jika nilai $\rho>\alpha=0,05$ berarti data menyebar secara homogen dan sebaliknya jika $\rho<\alpha=0,05$ berarti data menyebar tidak homogen

b. Pengujian Hipotesis: 
Pengujian hipotesis rerata nilai hasil belajar peserta didik dilakukan adalah untuk mengetahui kelompok sampel mana yang pengaruhnya lebih besar. Ouput yang digunakan untuk menguji hipotesis yaitu $T$-test untuk variansi data yang berpasangan adalah Paired Samples Test. Ringkasan hasil perhitungan T-test untuk masing-masing kelompok sampel dapat dilihat pada tabel berikut:

Tabel 6. Ringkasan Hasil Pengujian Hipotesis (t-test) Test of Homogeneity of Variances

\begin{tabular}{|c|c|c|c|c|c|c|c|}
\hline \multicolumn{3}{|c|}{ Kelompok Variansi } & T-Test & T-Tabel & Sig. ( $\rho)$ & $\alpha$ & Kesimpulan \\
\hline \multirow{2}{*}{$\begin{array}{l}\text { Nilai Hasil } \\
\text { Belajar }\end{array}$} & 1 & $\begin{array}{c}\text { Pretes \& Postes } \\
\text { (Kelompok Kecil) }\end{array}$ & 16.856 & 2,178 & 0,000 & \multirow{2}{*}{0,05} & Ho Ditolak \\
\hline & 2 & $\begin{array}{l}\text { Pretes \& Postes } \\
\text { (Kelompok Besar) }\end{array}$ & 25.095 & 2,064 & 0,000 & & Ho Ditolak \\
\hline
\end{tabular}

Sumber: Output Hasil Pengujian SPSS 21

Kriteria:

Taraf signifikansi $(\alpha)=0,05$

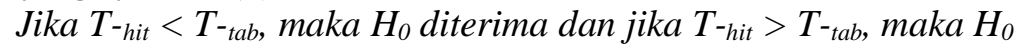
ditolak

Jika sig $(\rho)>\alpha=0,05$, maka $H_{0}$ diterima dan jika sig $(\rho)<\alpha=0,05$, maka $\mathrm{H}_{0}$ ditolak

Berdasarkan hasil uji-t berpasangan pada tabel di atas, diketahui bahwa; Pada data sampel kelompok kecil diperoleh nilai $\mathrm{t}_{\text {hitung }}=16,856>\mathrm{t}_{\text {tabel }}=2,178$ dan nilai probabilitas $(\rho) \operatorname{Sig}=0,000<$ $\alpha=0.05$, sedangkan data sampel kelompok besar diperoleh nilai $\mathrm{t}_{\text {hitung }}=25,095>\mathrm{t}_{\text {tabel }}=2,069$ dan nilai probabilitas $(\rho) \operatorname{Sig}=0,000<\alpha$ $=0.05$. Hasil pengujian hipotesis tersebut adalah keduanya menolak Ho, sehingga dapat dijelaskan bahwa pada populasi (dari mana sampel tersebut diambil) secara statistik ada perbedaan yang signifikan antara rata-rata nilai hasil belajar peserta didik pada kelompok kecil dan besar sebelum dengan sesudah perlakuan menggunakan bahan ajar IPA berbasis SETS. Nilai hasil belajar peserta didik sesudah diberi perlakuan lebih tinggi daripada sebelum perlakuan pembelajaran, artinya ada peningkatan nilai hasil belajar peserta didik setelah menggunakan bahan ajar IPA berbasis SETS pada konsep pencemaran lingkungan.

\section{2) Hasil Analisis Respon Siswa dan Guru terhadap Bahan Ajar}


Hasil penilaian siswa dan guru terhadap bahan ajar IPA yang dikembangkan diperoleh melalui instrumen angket (kuesioner) respon siswa dan guru. Hasil angket tersebut dapat dilihat pada gambar di bawah ini.

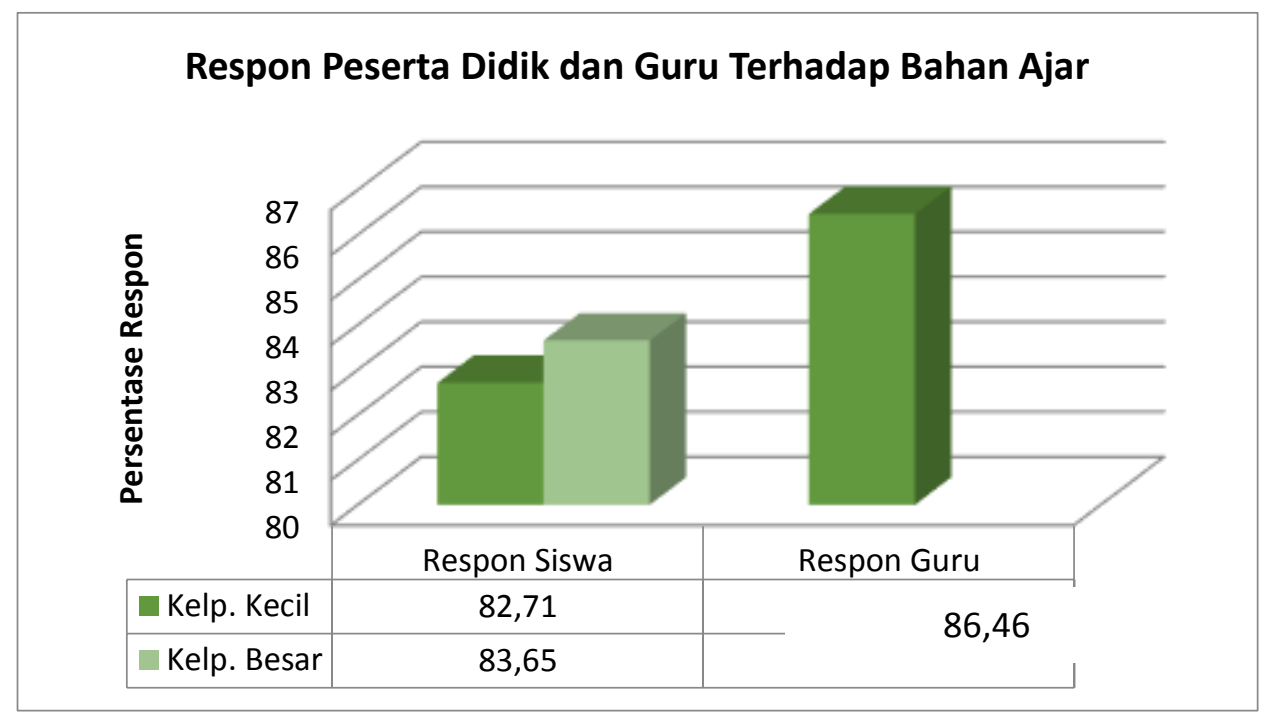

Gambar 3; Grafik Respon Siswa dan Guru Terhadap Bahan Ajar

Gambar 3 menunjukkan bahwa respon siswa terhadap bahan ajar IPA yang digunakan diperoleh $82,71 \%$ pada kelompok kecil dan $83,65 \%$ pada kelompok besar, sedangkan respon guru diperoleh $86,46 \%$. Skor persentase penilaian siswa dan guru secara keseluruhan berada pada interval $81,25 \%<\mathrm{p}$ $\leq 100 \%$, artinya bahan ajar yang dikembangkan adalah berkategori sangat baik untuk dijadikan sebagai bahan ajar pada materi pencemaran lingkungan.

Dari hasil analisis tersebut dapat dikatakan bahwa berdasarkan hasil pengamatan dan wawancara dengan guru bidang studi IPA di MTsN 1 Kendari, bahan ajar mengenai materi pencemaran lingkungan belum tersedia, sehingga peneliti fokus untuk mengembangkan sebuah produk berupa bahan ajar untuk memenuhi kebutuhan dalam pembelajaran IPA.

Produk yang dikembangkan adalah bahan ajar IPA yang berpendekatan SETS (Science, Environment, Technology, and Society). Pendekatan ini dipilih peneliti karena pendekatan ini langsung mengkaitkan sains dengan lingkungan, teknologi, dan masyarakat karena peserta didik mengalami langsung apa yang mereka pelajari dalam bahan ajar tersebut. Pendekatan SETS memiliki kelebihan yaitu peserta didik memperoleh peluang untuk memiliki pengetahuan sekaligus kemampuan berpikir kritis dan bertindak berdasarkan hasil analisis dan sintesis yang bersifat 
komprehensif dengan memperhitungkan aspek sains, lingkungan, teknologi, dan masyarakat sebagai satu kesatuan tak terpisahkan. ${ }^{17}$

Pengembangan bahan ajar berbasis SETS memuat potensi lokal yang ada di lingkungan sekitar sekolah dan tempat tinggal peserta didik yang dapat dimanfaatkan sebagai sumber belajar. Bahan ajar ini memuat uraian materi, tes, instrumen untuk mengukur tingkat pemahaman peserta didik. Bahan ajar disusun sedemikian rupa, sehingga memungkinkan peserta didik untuk belajar secara mandiri.

Bahan ajar yang dikembangkan dapat dikatakan layak untuk dipergunakan setelah memenuhi kriteria valid, praktis dan efektif. Berkaitan dengan kriteria tersebut dijelaskan oleh Asikin, bahwa sebuah produk baru yang dihasilkan dalam penelitian pengembangan minimal harus memenuhi 3 kriteria yaitu valid, praktis dan efektif. ${ }^{18}$ Suatu produk atau program dikatakan valid apabila dapat merefleksikan jiwa pengetahuan (state of the art of knowledge), yang bisa juga disebut validitas isi. Suatu produk dikatakan praktis apabila orang yang menggunakan produk tersebut menganggap bahwa produk yang dimaksud dapat digunakan (usable). Sedangkan produk disebut efektif apabila produk tersebut memberikan hasil sesuai dengan tujuan yang telah ditetapkan. Validasi produk dilakukan pada tahap pengembangan sebagaimana telah diuraikan sebelumnya, sedangkan uji kepraktisan dan keefektifan produk dilakukan pada tahap implementasi dan evaluasi.

\section{Hasil uji kevalidan}

Hasil uji kevalidan menunjukan bahwa bahan ajar IPA berbasis SETS menunjukan bahwa hasil penilaian oleh validator materi diperoleh $84,78 \%$, validator bahasa $91,3 \%$, validator media $91,67 \%$, dan validator penyajian $89,13 \%$. Skor persentase penilaian tersebut termasuk dalam rentang $81,25 \%$ $<\mathrm{p} \leq 100 \%$, artinya bahan ajar yang dikembangkan adalah valid dengan kategori sangat layak untuk dijadikan sebagai bahan ajar pada materi pembelajaran pencemaran lingkungan. Validator juga menambahkan saran soal-soal yang terdapat dalam bahan ajar dilengkapi dengan keterangan gambar atau grafik dan huruf yang digunakan untuk penulisan sumber gambar diperkecil lagi dan yang lainnya sudah dapat dilanjutkan.

Berdasarkan saran dan koreksi dari validator, materi yang diberikan masih lemah, maka langkah selanjutnya peneliti melakukan revisi produk tersebut. Dengan revisi produk berdasarkan saran validator materi, maka

${ }^{17}$ Binadja, Pedoman Praktis Pengembangan Bahan Ajar Bervisi dan Berpendekatan SETS. (Semarang: PPS Unnes Press, 2005)

18 Asikin, M.\& Cahyono, A.N. "Penelitian Pengembangan dalam Bidang Pendidikan". FMIPA Unnes. http://adinegara.com/wp-content/uploads/2011/06/makalah-Rn-D.pdf, diakses 1 September 2015. 
peneliti dapat meningkatkan kualitas materi pada bahan ajar IPA berbasis SETS pada konsep pencemaran lingkungan.

Dengan demikian, maka hasil uji kevalidan bahan ajar IPA berbasis SETS yang telah dilakukan oleh validator materi, bahasan penyajian dan media dapat dinyatakan bahwa secara keseluruhan bahan ajar IPA sangat layak untuk dikembangkan sebagai sumber belajar pada konsep pencemaran lingkungan.

\section{Hasil uji kepraktisan}

Hasil uji kepraktisan menunjukan bahwa produk bahan ajar IPA berbasis SETS yang diukur melalui instrumen pengamatan terhadap keterlaksanaan perangkat pembelajaran meliputi 1) aspek keterlaksanaan sintaks, 2) interaksi sosial, 3) prinsip reaksi, 4) sistem pendukung dan 5) aspek kemudahan dalam menggunakan bahan ajar.

Pengamatan dilakukan sebanyak tiga kali pertemuan masing-masing pada saat proses pembelajaran berlangsung baik pada sampel kelompok kecil maupun kelompok besar. Pada sampel kelompok kecil diperoleh hasil pengamatan pada pertemuan pertama bahwa aspek pertama, kedua dan kelima hanya terlaksana sebahagian (perlu revisi), sedangkan pada aspek ketiga dan empat adalah sudah terlaksana seluruhnya. Demikian pula pada pertemuan kedua dan ketiga ditemukan bahwa seluruh aspek sudah terlaksana seluruhnya.

Berkaitan dengan uraian tersebut, maka apabila dianalisis secara keseluruhan diperoleh bahwa skor rata-rata kelima aspek tersebut adalah 1,64 berada pada interval $1,5<\mathrm{M} \leq 2,00$ dan frekuensi relatif sebesar $81,78 \%$, artinya kelima aspek yang diukur pada umumnya telah terlaksana secara keseluruhan. Sedangkan pada sampel kelompok besar diperoleh hasil pengamatan pada pertemuan pertama bahwa aspek pertama, kedua, ketiga dan keempat sudah terlaksana seluruhnya, sedangkan pada aspek kelima hanya terlaksana sebahagian (perlu revisi). Demikian pula pada pertemuan kedua dan ketiga ditemukan bahwa seluruh aspek sudah terlaksana seluruhnya. Berkaitan dengan uraian tersebut, maka apabila disintesa secara keseluruhan diperoleh bahwa skor rata-rata kelima aspek tersebut adalah 1,79 berada pada interval 1,5<M $\leq 2,00$ dan frekuensi relatif sebesar 89,67\%, artinya kelima aspek yang diukur pada umumnya telah terlaksana secara keseluruhan. Berdasarkan hasil analisis terhadap kelima aspek yang diobservasi dalam keterlaksanaan bahan ajar pada sampel uji coba kelompok kecil dan besar sebagaimana telah uraian di atas, maka dapat dinyatakan bahwa bahan ajar IPA berbasis SETS sebagai produk dalam penelitian pengembangan ini dikatakan sebagai produk yang memiliki nilai kepraktisan untuk dapat diterapkan dalam proses pembelajaran.

\section{Hasil uji keefektifan produk}


Hasil uji keefektifan produk yang diukur dengan indikator keefektifan produk bahan pembelajaran dalam penelitian ini, yaitu (1) peningkatan hasil belajar peserta didik, (2) respon peserta didik terhadap bahan ajar IPA berbasis SETS, dan (3) respon guru terhadap bahan ajar IPA berbasis SETS. Berdasarkan indikator keefektifan produk bahan ajar yang dikembangkan, maka secara berurutan dijelaskan sebagai berikut:

\section{Analisis hasil belajar peserta didik}

Dalam penelitian ini, salah satu tujuan pengembangan bahan ajar adalah untuk meningkatkan pengetahuan (hasil belajar) peserta didik. Hasil belajar peserta didik adalah penguasaan materi pencemaran lingkungan, terutama yang terkait dengan pengertian sampah, pencemaran lingkungan dan konservasi lingkungan yang diukur melalui tes hasil belajar berdasarkan indikator yang telah ditentukan dalam mata pelajaran IPA pada peserta didik kelas VII semester genap pada MTs/SMP. Kemampuan kognitif peserta didik dalam bentuk pengetahuan tentang lingkungan hidup yang diukur dalam penelitian ini meliputi tiga aspek yaitu aspek pengetahuan $(\mathrm{C} 1)$, aspek pemahaman (C2) dan aspek aplikasi (C3). Untuk melihat adanya peningkatan pengetahuan lingkungan, tes kognitif diberikan pada awal atau sebelum menerima materi pembelajaran (pretes) dan pada akhir pembelajaran (postes). Pengukuran peningkatan hasil belajar peserta didik dilakukan baik pada sampel uji coba kelompok kecil maupun pada sampel uji coba kelompok besar.

Proses pembelajaran dilaksanakan setelah pretes dengan metode diskusi dan tanya jawab. Pertemuan pertama digunakan untuk membahas jenis-jenis pencemaran dan aktivitas manusia yang berpengaruh terhadap lingkungan dengan berpedoman pada lembar diskusi siswa dan modul. Siswa diminta membuat keterkaitan SETS dari topik yang dibahas pada kegiatan pembelajaran pertama ini. Pertemuan kedua membahas tentang klasifikasi sampah dan penanganan limbah dan siswa juga diminta membuat keterkaitan SETS dari topik yang dibahas pada kegiatan pembelajaran kedua. Pertemuan ketiga digunakan untuk dampak pencemaran dan pengelolaan sampah, serta membahas mengenai upaya yang dapat dilakukan manusia untuk menjaga lingkungannya.

Hasil belajar peserta didik pada sampel kelompok kecil sebelum diberikan perlakuan memiliki nilai rata-rata 50,67 dan setelah perlakuan meningkat menjadi 75,33. Begitu pula pada sampel kelompok besar nilai ratarata sebelum perlakuan 54,67 meningkat menjadi 79,33 setelah perlakuan. Hal ini disebabkan karena peserta didik pada kedua sampel tersebut sebelum diberikan perlakuan dimana tingkat pengetahuan mereka relatif sama, namun setelah diberikan perlakuan pembelajaran yaitu dengan menggunakan bahan ajar IPA berbasis SETS, hasil belajarnya meningkat yang disebabkan karena 
peserta didik merasa senang dan termotivasi serta mempunya ketertarikan terhadap bahan ajar yang digunakan.

Selanjutnya dilakukan pengujian hipotesis untuk mengetahui peningkatan hasil belajar peserta didik setelah diberikan perlakuan pembelajaran dengan menggunakan bahan ajar IPA berbasis SETS. Namun sebelum pengujian hipotesis terlebih dahulu dilakukan uji normalitas dan uji homogenitas varian dengan tujuan untuk mengetahui bahwa data kedua varian tersebut normal dan homogen.

Hasil uji kenormalan dan homogenitas data pada tabel 4 dan 5 di atas, menunjukkan bahwa data kedua varians tersebut adalah berdistribusi normal dan homogen. Sedangkan hasil pengujian hipotesis ditemukan bahwa terdapat perbedaan yang signifikan hasil belajar peserta didik sebelum perlakuan dan sesudah perlakuan. Perbedaan peningkatan hasil belajar kognitif juga disebabkan oleh aktivitas dan motivasi siswa dalam mengikuti proses pembelajaran sangat tinggi. Pernyataan ini dibuktikan dengan hasil angket tanggapan siswa yang diberikan pada akhir proses pembelajaran. Pembelajaran dengan pendekatan SETS menggunakan bahan ajar IPA berbasis SETS dengan memanfaatkan lingkungan sebagai sumber belajar membuat peserta didik tertarik mempelajari materi ini karena peserta didik dapat melihat dan mengalami secara langsung fenomena sains yang sedang mereka pelajari.

Hasil penelitian ini sejalan dengan penelitian Abdillah yang menyatakan bahwa terdapat perbedaan hasil belajar antara peserta didik yang menggunakan modul pembelajaran IPA terpadu dengan peserta didik yang tidak menggunakan modul pembelajaran. ${ }^{19}$ Demikian pula hasil penelitian Ragil dan Sukiswo yang menyatakan bahwa pembelajaran dengan menggunakan bahan ajar SETS dapat meningkatkan hasil belajar siswa. ${ }^{20}$ Peningkatan hasil belajar peserta didik disebabkan karena mereka sangat tertarik mengikuti pembelajaran yang mengaitkan antara unsur sains, lingkungan, teknologi, dan masyarakat.

Hasil analisis juga menunjukkan bahwa ketuntasan belajar paserta didik pada sampel kelompok kecil dan besar meningkat setelah diberikan perlakuan dengan menggunakan bahan ajar IPA berbasis SETS. Hal ini sesuai

${ }^{19}$ Abdillah F. "Penggunaan Modul sebagai Upaya Peningkatan Hasil Belajar Siswa dalam Mata Pelajaran TIK pada Materi Microsoft Word Kelas V SDN Sarikarya". Jurnal Elektronik Pendidikan Teknik Informatika, Vol. 2 No.1, (2013).

${ }^{20}$ Ragil dan Sukiswo, "Penerapan Pembelajaran Sains dengan Pendekatan SETS pada Materi Cahaya untuk Meningkatkan Hasil Belajar Siswa Kelas V SD”. Jurnal Pendidikan Fisika Indonesia, Vol. 7, (2010): 69-73 
dengan hasil penelitian Purwaningsih yaitu dengan pembelajaran menggunakan pendekatan SETS dapat meningkatkan ketuntasan klasikal. ${ }^{21}$

\section{Respon Peserta Didik terhadap Bahan Ajar}

Berdasarkan respon peserta didik terhadap bahan ajar IPA berbasis SETS diperoleh skor rata-rata sebesar $82,71 \%$ pada sampel kelompok kecil dan pada sampel kelompok besar diperoleh skor rata-rata sebesar 83,65\%. Kedua skor rata-rata tersebut termasuk dalam rentang $81,28 \%<\mathrm{P} \leq 100 \%$ dalam kriteria penskoran yang artinya bahan ajar dengan kategori sangat baik untuk diterapkan dalam pembelajaran materi pencemaran lingkungan.

Analisis respon peserta didik bahwa bahan ajar IPA berbasis SETS dengan kategori sangat baik memberikan kejelasaan bahwa bahan ajar sangat layak untuk diterapkan dalam pembelajaran materi pencemaran lingkungan. Hasil analisis ini juga menunjukkan bahwa pada umumnya peserta didik tertarik dengan pembelajaran menggunakan bahan ajar. Ketertarikan peserta didik terhadap pembelajaran sejalan dengan hasil penelitian Sudarman, bahwa melalui pendekatan kontekstual berwawasan SETS dengan menggunakan bahan ajar menunjukkan adanya peningkatan minat siswa. ${ }^{22}$ Peningkatan minat siswa ini dikarenakan siswa memperoleh ilmu dan pengalaman baru yang langsung berkaitan dengan yang ada di sekitar peserta didik. Peserta didik mengalami dan memperoleh langsung dari lingkungan hidup di sekitarnya yang dapat dimanfaatkan sebagai sumber belajar.

Pembelajaran dengan menggunakan bahan ajar IPA berbasis SETS juga mampu menumbuhkan rasa ingin tahu peserta didik, memberikan informasi baru, dan mendorong untuk mencari tambahan informasi yang lebih jauh yang dibuktikan dengan sebahagian besar peserta didik memberikan tanggapan positif. Peserta didik aktif bertanya terkait dengan apa yang sering dialami, seperti tentang bagaimana pengolahan sampah dan bagaimana apabila sampah dibakar. Peserta didik memperoleh informasi baru terkait pengolahan kotoran sapi menjadi produk yang bermanfaat untuk masyarakat, efek rumah kaca dan global warming, serta bahaya pencemaran lingkungan yang mengintai di sekitar tempat tinggal peserta didik. Informasi baru lain juga dapat siswa peroleh juga dari lembar diskusi siswa namun sulit untuk memperoleh informasi baru dari buku paket karena buku paket yang digunakan merupakan buku paket dengan tahun terbitan 1999. Pernyataan ini sejalan dengan hasil penelitian Juniati yaitu pelaksanaan pembelajaran dengan

21 Purwaningsih A. "Pembelajaran Kimia Berpendekatan SETS untuk Meningkatkan Kemampuan Berpikir Kritis dan Kreatif Siswa SMA Muhammadiyah 1 Semarang”. Skripsi. (Semarang: Jurusan Kimia FMIPA Unnes, 2005).

${ }^{22}$ Sudarman. Model Pengembangan Strategi Pembelajaran dalam Pembentukan Perilaku Berwawasan Linkungan. Jurnal Pendidikan Vokasi, Vo. 1, No. 1, (Februari, 2011): 69-90. 
menggunakan modul pembelajaran SETS meningkatkan motivasi peserta didik. $^{23}$

\section{Respon Guru terhadap Bahan Ajar}

Rata-rata nilai angket tanggapan/respon guru yaitu 41,5 atau $86,46 \%$. Nilai ini berada pada rentang $81,28 \%<\mathrm{P} \leq 100 \%$ dalam kategori penskoran yang artinya bahan ajar IPA berbasis SETS sangat baik atau sangat layak untuk diterapkan dalam pembelajaran materi Pencemaran Lingkungan. Guru juga memberikan tanggapan positif terkait penggunaan bahan ajar yang dapat dipelajari secara mandiri oleh peserta didik dan mempermudah peserta didik dalam mempelajari materi pencemaran lingkungan.

Kategori sangat baik untuk bahan ajar IPA berbasis SETS ditunjukkan dengan beberapa hal, diantaranya adalah susuna pembelajaran dalam bahan ajar dirumuskan secara jelas, tujuan pembelajaran yang tercantum di dalam bahan ajar dirumuskan dengan baik sesuai dengan Kompetensi Dasar dan indikator yang akan dicapai selama proses pembelajaran berlangsung. Pernyataan ini sesuai dengan Depdiknas mengenai peningkatan mutu pendidik, yaitu di dalam bahan ajar tercantum tujuan pembelajaran berdasarkan Standar Kompetensi yang akan dicapai siswa setelah mempelajari bahan ajar. ${ }^{24}$

Pendekatan SETS yang digunakan di dalam pembelajaran memanfaatkan bahan ajar dan sangat membantu peserta didik dalam meningkatkan pemahaman materi pencemaran lingkungan. Hal ini sejalan dengan hasil penelitian Achyani et al, bahwa pembelajaran yang mengkaitkan ilmu pengetahuan yang dimiliki peserta didik dengan kehidupan nyata dan fenomena yang terjadi di alam sekitar dapat merangsang dan memotivasi peserta didik sehingga prestasi belajar peserta didik dapat meningkat. ${ }^{25}$ Peningkatan pemahaman peserta didik dibuktikan dengan meningkatnya hasil belajar dan ketuntasan belajar yang dicapai peserta didik yang diperoleh melalui penggunaan bahan ajar dalam pembelajaran dengan pendekatan SETS yang mengkaitkan empat komponen penyusunnya yaitu sains, lingkungan, teknologi, dan masyarakat.

${ }^{23}$ Juniati, "Peningkatan Aktivitas, Motivasi dan Hasil Belajar Peserta Didik dengan Metode SETS di SMP Negeri Purworejo, Jawa Tengah". Jurnal Berkala Fisika Indonesia (Semarang: Universitas Negeri Semarang, Vol. 2, No. 1, (2009):15-20

${ }^{24}$ Depdiknas, Penulisan Modul. (Jakarta: Direktorat Tenaga Kependidikan dan Peningkatan Mutu Pendidik dan Tenaga Kependidikan, 2008), h. 29

${ }^{25}$ Achyani et al, "Model Penulisan Buku Ajar Biologi SMA Berwawasan Ekologi dan Lokal untuk Meningkatkan Kepedulian Siswa terhadap Lingkungan". Jurnal Penelitian Pendidikan UMM, Vol. 1 No. 1, (Mei, 2010). 


\section{F. PENUTUP}

Hasil uji kevalidan bahan ajar IPA berbasis SETS yang telah dilakukan oleh pakar materi sebesar $88,41 \%$, pakar media sebesar $93,06 \%$ dan secara keseluruhan diperoleh nilai hasil uji validitas dengan rata-rata 89,57\% yang artinya bahan ajar valid dan sangat layak untuk digunakan dalam pembelajaran IPA pada konsep pencemaran lingkungan.

Hasil uji kepraktisan produk bahan ajar IPA berbasis SETS yang diukur melalui instrumen pengamatan terhadap keterlaksanaan perangkat pembelajaran meliputi 1) aspek keterlaksanaan sintaks, 2) interaksi sosial, 3) prinsip reaksi, 4) sistem pendukung dan 5) aspek kemudahan dalam menggunakan bahan ajar pada ujicoba sampel kelompok kecil diperoleh skor rata-rata kelima aspek tersebut adalah 1,64 berada pada interval $1,5<\mathrm{M} \leq$ 2,00 dan frekuensi relatif sebesar $81,78 \%$, artinya kelima aspek yang diukur pada umumnya telah terlaksana secara keseluruhan, sedangkan pada sampel kelompok besar diperoleh skor rata-rata kelima aspek tersebut adalah 1,79 berada pada interval $1,5<M \leq 2,00$ dan frekuensi relatif sebesar $89,67 \%$, artinya kelima aspek yang diukur pada umumnya telah terlaksana secara keseluruhan. Dengan demikian, maka dapat disimpulkan bahwa bahan ajar IPA berbasis SETS sebagai produk dalam penelitian pengembangan ini dikatakan sebagai produk yang memiliki nilai kepraktisan dengan kategori sangat baik untuk dapat diterapkan dalam proses pembelajaran.

Hasil uji keefektifan produk yang diukur dengan indikator keefektifan produk, yaitu 1) peningkatan hasil belajar peserta didik, dan 2) respon peserta didik dan guru terhadap bahan ajar. Hasil pengujian hipotesis uji rerata hasil belajar peserta didik sebelum dan sesudah diberikan perlakuan pembelajaran dengan menggunakan bahan ajar IPA berbasis SETS adalah berbeda secara signifikan, artinya hasil belajar peserta didik sebelum diberikan perlakuan meningkat menjadi lebih baik setelah penggunaan bahan ajar IPA berbasis SETS di MTsN 1 Kendari. Sedangkan respon siswa dan guru terhadap bahan ajar yang digunakan diperoleh skor rata-rata sebesar $82,71 \%$ pada sampel kelompok kecil dan pada sampel kelompok besar diperoleh skor rata-rata sebesar $83,65 \%$. Kedua skor rata-rata tersebut termasuk dalam rentang $81,28 \%<\mathrm{P} \leq 100 \%$, artinya bahan ajar dengan kategori sangat baik atau sangat layak untuk diterapkan dalam pembelajaran materi pencemaran lingkungan di MTsN 1 Kendari.

Dengan demikian bahan ajar IPA berbasis SETS yang dikembangkan sangat layak apabila digunakan sebagai bahan ajar untuk menyampaikan materi Pencemaran Lingkungan dalam meningkatkan hasil belajar kognitif peserta didik kelas VII di MTsN 1 Kendari.

\section{DAFTAR PUSTAKA}


Abdillah F. "Penggunaan Modul sebagai Upaya Peningkatan Hasil Belajar Siswa dalam Mata Pelajaran TIK pada Materi Microsoft Word Kelas V SDN Sarikarya". Jurnal Elektronik Pendidikan Teknik Informatika, Vol. 1, No. 1, (2013).

Achyani et al. "Model Penulisan Buku Ajar Biologi SMA Berwawasan Ekologi dan Lokal untuk Meningkatkan Kepedulian Siswa terhadap Lingkungan”. Jurnal Penelitian Pendidikan UMM, Vol. 1, No. 1, (Mei, 2010).

Anwar, Syaeful, Pengolahan Bahan Ajar. Bandung: UPI Press, 2014.

Asikin, M.\& Cahyono, A.N. Penelitian Pengembangan dalam Bidang Pendidikan. FMIPA Unnes. http://adinegara.com/wp-content/uploads/2011/06/makalahR-n-D.pdf. Diakses 1 September 2016

Binadja, Achmad, Pendidikan IPA dan Pemikiran dalam SETS (Science, Enviroment, Technology, Society. Semarang: PPS Unnes Press, 2002.

, Pedoman Praktis Pengembangan Bahan Ajar Bervisi dan Berpendekatan SETS. Semarang: PPS Unnes Press, 2005.

Borich, Gary D. Effective Teaching Methods Reasearch Based Practice. New Jersey: Pearson Education Inc, 2007.

Carin dan Sund. Teaching Science Trough Discovery. Columbus: Merril Publishing Company, 1993.

Depdiknas. Model Pengembangan Silabus Mara Pelajaran dan Rencana Pelaksanaan Pembelajaran IPA Terpadu SMP/MTs. Jakarta: Pusat Kurikulum. Balitbang Depdiknas, 2006a.

- Penulisan Modul. Jakarta: Direktorat Tenaga Kependidikan dan Peningkatan Mutu Pendidik dan Tenaga Kependidikan, 2008.

Frank dan Barzilai. "Project-Based Technology: Instructional Strategy for Developing Technological Literacy". Journal of Technology Education, Vol. 18, No. 1, (2011): 39-53.

Juniati, Peningkatan Aktivitas, Motivasi dan Hasil Belajar Peserta Didik dengan Metode SETS di SMP Negeri Purworejo, Jawa Tengah. Jurnal Berkala Fisika Indonesia (Semarang: Universitas Negeri Semarang, Vol. 2, No. 1, (2009):15-20.

Kumala, D. Pengembangan Perangkat Pembelajaran IPA Terpadu dengan Setting Inkuiri Terbimbing untuk Meningkatkan Pemahaman Konsep dan Kinerja Ilmiah Siswa. E-Journal Program Pascasarjana Universitas Pendidikan Ganesha, 2013.

Listyawati. Pengembangan Perangkat Pembelajaran IPA Terpadu di SMP. Journal of Innovative Science. Vol. 1, (2012): 61- 69.

M. Lang \& Olson, Integrated Science Teaching as a Challenge for Teachers to Develop New Conceptual Structures. Journal Research in Science Education, Vol. 30, No. 2, (2000): 213-224

Permendiknas No 22 Tahun 2006 tentang Standar Isi Satuan Pendidikan Dasar dan Menengah. http://www.permen_22_2006.pdf. Diakses 30 Maret 2016. 
Purwaningsih A. "Pembelajaran Kimia Berpendekatan SETS untuk Meningkatkan Kemampuan Berpikir Kritis dan Kreatif Siswa SMA Muhammadiyah 1 Semarang". Skripsi. (Semarang: Jurusan Kimia FMIPA Unnes, 2005).

Ragil dan Sukiswo. "Penerapan Pembelajaran Sains dengan Pendekatan SETS pada Materi Cahaya untuk Meningkatkan Hasil Belajar Siswa Kelas V SD". Jurnal Pendidikan Fisika Indonesia, Vol. 7, (2010): 69-73.

Soegiranto, Acuan Penulisan Bahan Ajar Dalam Bentuk Modul. Provinsi Nusa Tenggara Timur: Pokja Kurikulum dan Supervisi Pusat Pengembangan Madrasah Kementrian Agama, 2010.

Sudarman, Model Pengembangan Strategi Pembelajaran dalam Pembentukan Perilaku Berwawasan Linkungan. Jurnal Pendidikan Vokasi. Vol. 1, No. 1, (Februari, 2011): 69-90.

Sukardjita, IW. "Pengembangan Model Pembelajaran IPA MOTORIC Berwawasan Lingkungan Bagi Siswa SMP di Kota Kupang”. Diisertasi Doktor, Makassar: PPs UNM, 2015.

Trianto. Model Pembelajaran Terpadu. Jakarta: Bumi Aksara, 2011.

Woolnough, B. Practical Work in Science. Cambridge: University Press, 1991.

Yuliati, L. Efektivitas Bahan Ajar IPA Terpadu terhadap Kemampuan Berpikir Tingkat Tinggi Siswa SMP, Jurnal Pendidikan Fisika Indonesia, Vol. 9, (2013): 53-57. 